\title{
A randomized direct comparison of the pharmacokinetics and pharmacodynamics of apixaban and rivaroxaban [Corrigendum]
}

Frost C, Song Y, Barrett YC, et al. Clin Pharmacol. 2014;6:

179-187.

Page 183, Figure 2, the arithmetic mean apixaban trough concentration on Day 4 prior to the morning dose (ie, $0-\mathrm{hr}$ Figure 2) was not correct. The arithmetic mean (SD) apixaban trough concentration on Day 4 prior to the morning dose was $24.6(6.1) \mathrm{ng} / \mathrm{mL}$. The correct figure is shown below.
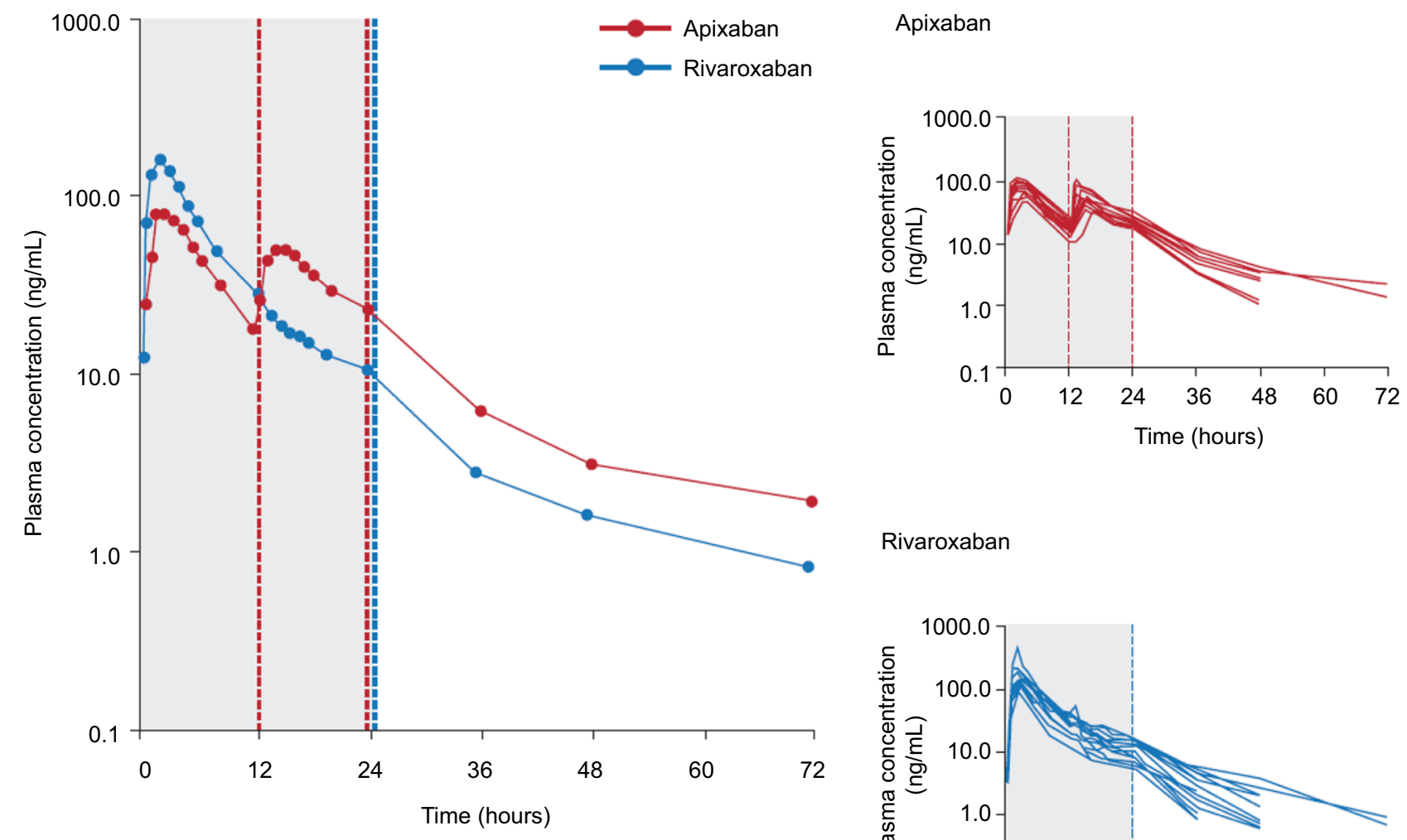

Rivaroxaban

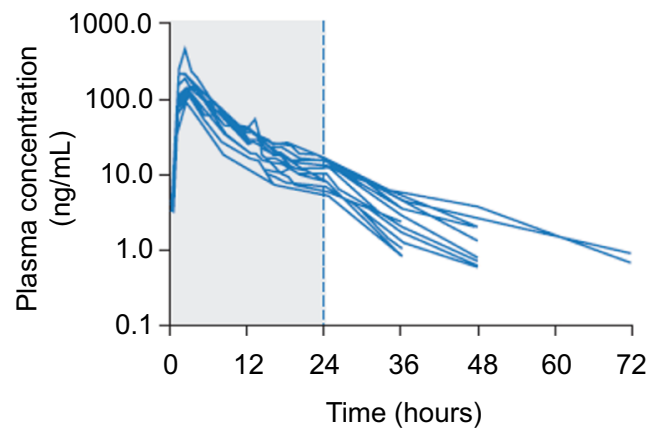

Clinical Pharmacology: Advances and Applications

Dovepress

\section{Publish your work in this journal}

Clinical Pharmacology: Advances and Applications is an international, peer-reviewed, open access journal publishing original research, reports, reviews and commentaries on all areas of drug experience in humans.

The manuscript management system is completely online and includes

a very quick and fair peer-review system, which is all easy to use.

Visit http://www.dovepress.com/testimonials.php to read real quotes from published authors.

Submit your manuscript here: https://www.dovepress.com/clinical-pharmacology-advances-and-applications-journal 